\title{
Aktivitas Antimikroorganisme Ekstrak Etanol 70 \% Biji Bengkuang terhadap Staphylococcus epidermidis, Pseudomonas aeruginosa dan Candida albicans
}

\section{Antimicroorganism Activity Of 70 \% Ethanolic Extract Of Pachyrrizus Erosus Seed Against Staphylococcus Epidermidis, Pseudomonas Aeruginosa, And Candida Albicans}

\author{
Min Rahminiwati ${ }^{*}$, Joshie Ramadhan ${ }^{1}$, Oom Komala ${ }^{2}$ \\ ${ }^{1}$ Divisi Farmakologi, Departement Anatomi Fisiologi dan Farmakologi Fakultas Kedokteran Hewan, \\ Institut Pertanian Bogor \\ ${ }^{2}$ Fakultas Matematika dan Ilmu Pengetahuan Alam Universitas Pakuan Bogor. \\ *Email: minrahminiwati@yahoo.com
}

Naskah diterima: 28 Maret 2019, direvisi: 21 September 2020, disetujui: 20 Nopember 2020

\begin{abstract}
Biopesticida effect of ethanolic extract of Pachyrrizus erosus seed and antibacterial activity of this extract on Staphylococcus and E. coli as well as antifungal against Candida albicans have been known very well. However its anti-microorganism activity against Staphylococcus epidermidis and Pseudomonas aeruginosa have not been reported. In this study we determined the antibacterial activity of seed extract of Pachyrrizus erosus against Staphylococcus epidermidis, Pseudomonas aeruginosa and Candida albicans using agar disc diffusion technique and dilution method. The anti-microorganism activity of extract was tested at concentration 10\% 12\% $14 \%$ $16 \%$ As control of antibacterial, antifungal activity are eritromisin and ketokonazol at concentration $10 \mathrm{ppm}$ respectivelly as well as aquadestilata as negative control. The data showed that the extract potentially effective as anti-microorganism against Staphylooccus epidermidis and Pseudomonas aeruginosa as well as against Candida albicans at concentration of $10 \mathrm{mg} / \mathrm{ml}$ as minimum bactericidal concentration.
\end{abstract}

Key words: Eritromisin Pseudomonas biji bengkuang Candida albicans; Ketokonazol

\begin{abstract}
Abstrak
Ekstrak etanol $70 \%$ biji bengkuang selain berpotensi sebagai biopestisida, juga dilaporkan mempunyai aktivitas antibakteri terhadap bakteri gram positif Staphylococcus aureus dan bakteri gram negatif Escherichia coli serta Candida alibican. Namun efeknya terhadap Staphylococcus epidermidis dan Pseudomonas aeruginosa, belum dketahui. Penelitian ini ditujukan untuk menentukan aktivitas antimikroorganisme ekstrak etanol $70 \%$ biji bengkuang lokal terhadap Staphylococcus epidermidis, Pseudomonas aeruginosa dan Candida Albicans menggunakan teknik difusi agar dan metoda dilusi. Aktivitas antimikroorganisme ekstrak diteliti pada konsentrasi $10 \%, 12 \%, 14 \%, 16 \%$ dan sebagai kontrol negatif, kontrol positif antibakteri dan kontrol positif antifungal masing masing digunakan akuadestilata, ertromisin $10 \mathrm{ppm}$, ketokonazol $10 \mathrm{ppm}$. Data yang diperoleh menunjukkan bahwa ekstrak efektif sebagai antibakteri terhadap Staphylococcus epidermidis dan Pseudomonas aeruginosa serta sebagai antifungi terhadap Candida albicans, pada konsentrasi bunuh minimum $10 \mathrm{mg} / \mathrm{ml}$.
\end{abstract}

Kata kunci: Eritromisin Pseudomonas biji bengkuang Candida albikan; Ketokonazol 


\section{Pendahuluan}

Tanaman bengkuang merupakan tumbuhan semak semusim dan membelit yang dapat tumbuh dengan baik di lingkungan yang lembab panas, panas dan bebas bunga es. (Rubatzky dkk., 1998). Umbi bengkuang mengandung serat, inulin, vitamin $\mathrm{C}$, flavonoid dan daidzein yang bermanfaat sebagai prebiotik, antidiabetes mellitus, immunomodulator, fitoestrogen dan kecantikan (Roberfroid, 2005; Kumalasari et al., 2014; Nines, 1999). Biji bengkuang mengandung, isoflavonoid, tanin, saponin dan zat nutrisi seperti proteins, lipids, $\mathrm{Fe}$ dan $\mathrm{Ca}$, dan rotenoid (Santos et al., 1996; Bella and Lynn, 1953; Parra et al., 2014). Rotenoid adalah suatu flavonoid yang mempunyai efek sebagai inhibitor enzim-enzim pernapasan yang kuat yang menyebabkan transport elektron pada sistem pernapasan terhambat dan akhirnya sintesa ATP sebagai sumber energi ditekan. Namun demikian, rotenon dilaporkan mempunyai banyak manfaat diantaranya sebagai insektisida, obat kulit dan antifungal (Necha et al., 2004). Efek ekstrak bengkuang terhadap Candida albicans dilaporkan oleh Wiredu (2014). Wiredu (2014) mengemukakan adanya perbedaan potensi antifungi yang signifikan antara bagian akar daun dan biji yang diduga berkaitan dengan perbedaan kandungan kimia diantara bagian bagian tanaman bengkuang.

Potensi biji bengkuang sebagai antibakteri dikemukakanolehJuriah(2003) dan Wiredu(2004). Kedua peneliti ini menyatakan bahwa ekstrak biji bengkuang mempunyai aktivitas antibakteri terhadap bakteri gram positif Staphylococcus aureus dan gram negatif Escherichia coli. Namun, efektivitas antimikroba ekstrak biji bengkuang terhadap bakteri gram negatif Pseudomonas aeruginosa, bakteri gram positif Staphylococcus epidermidis belum pernah dilaporkan.

Pseudomonas aeruginosa merupakan bakteri yang terdapat di tanah dan air. Sekitar 10\% Pseudomonas aeruginosa merupakan flora normal di kolon (usus besar). Selain itu, bakteri ini juga dapat dijumpai pada daerah lembab di kulit dan saluran pernapasan bagian atas pasienpasien rumah sakit (Levinson and Jawetz, 2003). Pseudomonas aeruginosa merepresentasikan permasalahan yang terkait dengan bakteri yang resisten terhadap antimikroba Resistensi terhadap antimikroba, disamping adanya mekanisme alami dan labilitas genetik yang tinggi, bakteri ini secara terus menerus mengisi persenjataannya dari mekanisme resistensi yang didapat sehingga kecenderungan untuk menyebarkan resistensi secara global cukup tinggi (Zavascki et al., 2010; Zowalaty et al., 2015; Woodforf et al., 2011)

Staphylococcus epidermidis terdapat pada kulit manusia, saluran pernapasan dan saluran pencernaan. Bakteri ini menyebabkan pembengkakan seperti jerawat, infeksi luka, infeksi saluran kemih dan infeksi ginjal (Radji, 2011). Penularan penyakit yang disebabkan oleh Staphylococcus epidermidis dapat terjadi melalui kontak dengan peralatan yang terkontaminasi karena Staphylococcus epidermidis memiliki kemampuan membentuk biofilm diatas permukaan peralatan sehingga penularan penyakit akan terjadi dengan mudah dilingkungannya. Individu yang mempunyai imunitas rendah mudah terinfeksi oleh bakteri ini.

Candida sp. merupakan flora normal yang biasanya terdapat di kulit tubuh, kulit kepala, mulut, sela-sela jari kaki, di dalam usus, di paru-paru, dan di vagina. Fungi ini menginfeksi berbagai bagian tubuh, seperti mulut, vagina, kulit dan paru-paru (Wesley dan Margaret, 1989). Selain menyerang manusia, candidiasis juga dapat menyerang berbagai jenis unggas terutama ayam, kalkun, burung puyuh dan angsa. Suatu study yang dilakukan terhadap 317 pasien yang meliputi 154 manusia, 69 anjing 21 kerbau, 6 kuda dan 4 kambing semuanya di suspect terkena infeksi fungi. Manifestasi penyakit ini pada hewan secara klinis dapat berupa mastitis subklinis, stomatitis, dermatitis dan otitis (Jadhav and Pal, 2013)

Tujuan dari penelitian ini adalah meneliti aktivitas antimikroba ekstrak biji bengkuang terhadap bakteri Staphylococcus epidermidis, Pseudomonas aeruginosa, dan fungi Candida albicans serta menetapkan konsentrasi ekstrak biji tanaman bengkuang (Pachyrrizus erosus) yang dapat membunuh ketiga mikroorganisme tersebut. Parameter yang diamati meliputi Konsentrasi Bunuh Minimal (KBM) dan Lebar Daerah Hambat. 


\section{Materi dan Metode}

Bahan-bahan yang digunakan dalam penelitian ini adalah biji tanaman bengkuang, yang diperoleh dari Pasar Induk daerah Bogor, etanol 70\%, pereaksi Dragendorf, pereaksi Mayer, pereaksi Wagner, $\mathrm{FeCl}_{3} 1 \%$, asam klorida $2 \mathrm{~N}$, magnesium $(\mathrm{Mg})$, media Natrium Agar (NA), Media PDA ( Potato Dextrose Agar), Staphylococcus epidermidis, Pseudomonas aeruginosa, Candida albicans, $\mathrm{NaCl}$ 0,9\%, Natrium gelatin 10\%, eritromisin, ketokonazol, dan akuades.

Alat-alat yang digunakan diantaranya rotary evaporator, oven, neraca analitik, tabung reaksi, cawan petri, autoklaf, inkubator, krus, kertas cakram, ayakan mesh 40, moisture balance, lemari pendingin, lup inokulasi, kain batis, Vaccum drier, api bunsen, jarum ose, sentrifugator dan peralatan gelas lainnya.

Biji tanaman bengkuang yang telah dideterminasi di Lembaga Ilmu Pengetahuan Indonesia (LIPI) disortasi basah kemudian dicuci bersih menggunakan air mengalir. Setelah dikeringkan di dalam oven dengan suhu $40^{\circ} \mathrm{C}$ selama \pm 3 hari, biji bengkuang dibersihkan kembali dari kotoran yang masih menempel kemudian digiling dan diayak menggunakan ayakan mesh 40 (DepKes RI, 1985). Serbuk yang diperoleh digunakan untuk penentuan kadar air dan kadar abu, uji fitokimia dan pembuatan ekstrak.

Penentuan kadar air serbuk dilakukan dengan menggunakan alat moisture balance. Sebanyak $1 \mathrm{~g}$ serbuk disimpan diatas punch yang telah dipanaskan dan ditara. Serbuk diratakan dalam punch dan dibakar pada suhu $105^{\circ} \mathrm{C}$ selama kurang lebih 10 menit. Penentuan kadar air dilakukan duplo. Kadar air simplisia pada umumnya ditetapkan $\leq 10 \%$ (DepKes RI, 1977).

Pada penentuan kadar abu sebanyak 2 - 3 g serbuk simplisia dimasukkan ke dalam krus platina atau krus silikat yang telah dipijarkan dan ditara dalam keadaan dingin. Serbuk dalam krus diratakan dan dipijarkan perlahan-lahan hingga arang habis, kemudian didinginkan dan ditimbang. Kadar abu dihitung terhadap bahan yang telah dikeringkan diudara (DepKes RI, 2000). Kadar abu simplisia pada umumnya tidak lebih dari $3,5 \%$.
Cara perhitungannya :

Kadar $\mathrm{Abu}=\frac{(\text { bobot krus+abu) }- \text { bobot krus kosong }}{\text { bobot sampel }} \times 100 \%$

Ekstraksi serbuk biji bengkuang dilakukan dengan cara maserasi dingin. Seratus gram serbuk biji bengkuang dimaserasi dalam $350 \mathrm{~mL}$ etanol $70 \%$ selama 24 jam dengan pengocokan dilakukan setiap 6 jam sekali. Pada jam ke 24 maserat disaring menggunakan kain batis. Filtrat yang diperoleh disimpan dalam suhu kamar. Residunya diremaserasi 2 kali menggunakan pelarut alkohol yang baru. Total pelarut alkohol yang digunakan untuk mengekstrak $100 \mathrm{~g}$ serbuk biji adalah $1000 \mathrm{~mL}$. Semua maserat (filtrat) dari masing masing proses maserasi dikumpulkan kemudian dienaptuangkan selama 24 jam. Larutan hasil tuangan dikeringkan dengan Vaccum drier. Rendemen ekstrak kering yang diperoleh dihitung dengan cara sebagai berikut.

Rendemen Ekstrak $=\frac{\text { bobot ekstrak }}{\text { bobot simplisia }} \times 100 \%$.

Ekstrak yang diperoleh disimpan dalam desikator untuk selanjutnya digunakan dalam uji fitokimia dan uji antimikroba.

Uji fitokimia yang meliputi penentuan senyawa golongan alkaloid, flavonoid, tanin dan saponin dilakukan sebagai salah satu upaya stadardisasi bahan baku.

Penentuan golongan alkaloid dilakukan mengikuti protokol yang terdapat dalam DepKes RI (1980). Satu mL HCl 2 N, dan 9 mL air suling berturut turut ditambahkan ke dalam $0,5 \mathrm{~g}$ ekstrak biji bengkuang, kemudian dipanaskan selama 2 menit. Setelah didinginkan larutan disaring dan filtrat yang diperoleh dimasukkan ke dalam 3 tabung yang berbeda masing masing sebanyak $1 \mathrm{~mL}$. Dua tetes pereaksi Wagner, dimasukkan ke dalam tabung pertama, pereaksi Dragendorf ke dalam tabung kedua dan pereaksi Mayer ke dalam tabung ketiga. Reaksi dinyatakan positif mengandung alkaloid jika dengan penambahan pereaksi Wagner, terbentuk warna coklat sampai hitam, warna merah atau jingga dengan penambahan Dragendorf dan warna putih atau kuning dengan penambahan pereaksi Mayer (DepKes RI, 1980). 
Penentuan senyawa golongan flavonoid dilakukan terhadap kurang lebih 0,5 g ekstrak biji bengkuang. Biji bengkuang dimasukkan ke dalam $100 \mathrm{~mL}$ air panas, kemudian didihkan selama 5 menit dan disaring. Serbuk Mg sebanyak 0,5 g, $\mathrm{HCl}$ pekat dan amil alkohol berturut turut di masukkan ke dalam $5 \mathrm{~mL}$ filtrat yang diperoleh. Terbentuknya warna kuning merah atau jingga dalam larutan amil alkohol setelah dikocok kuat kuat dan dibiarkan memisah menunjukan adanya senyawa golongan flavanoid (DepKes RI, 1980).

Ekstrak bengkuang sebanyak 0,2 g untuk penentuan senyawa golongan tannin, setelah ditambah $5 \mathrm{~mL}$ air suling panas diaduk dalam tabung kemudian didinginkan dan diendapkan menggunakan centrifuse. Bagian yang cair dipisahkan dari bagian yang padat dengan cara di dekantisir. $\mathrm{NaCl}$ 0,9\% ditambahkan ke dalam bagian yang cair dan disaring kemudian ke dalam $1 \mathrm{~mL}$ filtrat yang diperoleh ditambahkan larutan gelatin 10\% sebanyak $3 \mathrm{~mL}$. Endapan yang terbentuk setelah penambahan gelatin $10 \%$ menunjukkan larutan positif mengandung tanin (Fransworth, 1966).

Ekstrak biji bengkuang sebanyak 0,5 g dilarutkan dalam $10 \mathrm{~mL}$ air panas kemudian didinginkan dan dikocok kuat-kuat selama 10 detik. Hasil dinyatakan positif mengandung saponin bila terbentuk buih yang mantap selama tidak kurang dari 10 menit, setinggi $1 \mathrm{~cm}$ sampai $10 \mathrm{~m}$ dan pada penambahan 1 tetes asam klorida 2 N, buih tidak hilang (DepKes RI, 1978).

Pengujian aktivitas antimikroba ekstrak dilakukan pada isolat bakteri dan fungi. Isolat bakteri ditumbuhkan pada media agar miring NA sedangkan untuk fungi pada media PDA (Potato Dextrose Agar) yang steril. Media biakan diinkubasi pada suhu $37^{\circ} \mathrm{C}$ selama 24 jam, Setelah tumbuh, biakan disimpan pada lemari pendingin suhu $4^{\circ} \mathrm{C}$ sebagai stok.

\section{Penentuan KBM dan LDH}

Staphylococcus epidermidis, Pseudomonas aeruginosa, masing masing sebanyak satu ose secara terpisah dimasukkan ke dalam tabung yang berisi $\mathrm{NaCl} 0,9 \%$ sebanyak $9 \mathrm{~mL}$ untuk membuat stok suspense bakteri dan jamur. Suspensi dihomogenkan dengan cara pengocokan (pengenceran $10^{-1}$ ), selanjutnya dari stok suspensi tersebut dibuat pengenceran berseri $10^{-2}, 10^{-}$ ${ }^{3}, 10^{-4}$ sampai $10^{-6}$ dengan menggunakan $\mathrm{NaCl}$ $0.9 \%$ sebagai larutan pengencer. Khusus untuk untuk Candida albicans, pengenceran tertinggi dilakukan sampai dengan pengenceran $10^{-4}$. Satu $\mathrm{mL}$ biakan dari masing-masing pengenceran diambil dan dicampurkan ke dalam $20 \mathrm{~mL}$ media agar cair suhu $45^{\circ} \mathrm{C}$. Media cair dituangkan ke dalam cawan petri yang telah disterilkan diikuti dengan menggerakkan cawan seperti angka 8 atau dengan gerakkan melingkar supaya pertumbuhan bakteri merata. Jumlah koloni agar dihitung setelah diinkubasi pada $37^{\circ} \mathrm{C}$ selama 24 jam. Perhitungan jumlah koloni dilakukan sebelum perlakuan untuk memenuhi persyaratan uji, yaitu antara 30-300 koloni setiap cawan.

\section{Penyiapan Larutan Uji, Larutan Kontrol dan Kertas Cakram}

Larutan ekstrak diuji aktivitas antimikroorgansimenya pada konsentrasi 10\%, 7,5\%, $5 \%$, 2,5\% pada penentuan Konsentrasi Bunuh Minimum (KBM) dan 10\%, 12\%, 14\%,16\% pada penentuan Lebar Daerah Hambat (LDH). Sebagai kontrol positif untuk bakteri gram positif dan negatif digunakan larutan eritromisin $10 \mathrm{ppm}$, untuk kontrol positif fungi digunakan ketokonazol $10 \mathrm{ppm}$. dan sebagai kontrol negatifnya digunakan akuades.

Kertas cakram berukuran $6 \mathrm{~mm}$ disterilisasi dengan cara meletakkan kertas cakram dalam cawan petri kemudian dimasukkan ke dalam autoklaf $121^{\circ} \mathrm{C}$, 1 atm selama 15 menit. Kertas cakram steril secara terpisah ditetesi larutan uji dan kontrol positif serta kontrol negatif masingmasing $20 \mu \mathrm{L}$. Selanjutnya kertas cakram tersebut dikeringkan pada suhu $37^{\circ} \mathrm{C}$ sampai kering dan siap digunakan.

\section{Penentuan Konsentrasi Bunuh Minimum (KBM)}

Konsentrasi Bunuh Minimum (KBM) adalah konsentrasi terkecil yang dapat membunuh mikroorganisme. Nilai KBM ditetapkan berdasarkan pada tidak adanya pertumbuhan Staphylococcus epidermidis, Pseudomonas aeruginosa dan Candida albicans dipermukaan media yang menandakan masing-masing mikroba uji mati karena larutan uji pada konsentrasi tersebut. 
(McKane dan Kandel, 1996; Koneman et al., 1997).

Penentuan Konsentrasi Bunuh Minimum (KBM) dilakukan dengan menggunakan metode dilusi agar. Sebanyak $20 \mathrm{~mL}$ media NA untuk bakteri dan $20 \mathrm{~mL}$ media PDA untuk jamur, yang telah disterilkan dimasukkan ke dalam cawan petri dengan cara aseptis diikuti dengan penambahan ekstrak pada berbagai konsentrasi sebanyak 1 $\mathrm{mL}$. Selanjutnya media tersebut diaduk sampai homogen dan dibiarkan sampai mengeras. Sediaan bakteri untuk penentuan KBM dibuat pada konsentrasi bakteri $10^{-6}$, sedangkan untuk jamur dibuat konsentrasi $10^{-4}$. Penentuan konsentrasi dilakukan dengan menentukan kekeruhan menurut standar Mc Farland. Sebanyak 0,2 mL bakteri yang sudah disiapkan disebar diatas permukaan media NA yang sudah mengeras sedangkan untuk jamur disebar diatas permukaan media Potato Dextrose Agar (PDA). Pengamatan terhadap pertumbuhan mikroorganisme dilakukan pada media yang telah diinkubasi selama 24 jam pada suhu $37^{\circ} \mathrm{C}$.

\section{Pengujian Lebar Daerah Hambatan (LDH)}

Inokulum mikroba dari hasil pengenceran diambil sebanyak 0,2 $\mathrm{mL}$, dicampurkan ke dalam media NA untuk bakteri atau media PDA untuk jamur. Setelah diratakan dengan menggunakan spreader agar menyebar merata, kertas cakram yang sudah berisi larutan ekstrak 10\%, 12\%, $14 \%, 16 \%$, dan kontrol diletakkan di atas media agar kemudian dimasukkan ke dalam inkubator. Inkubasi dilakukan selama 24 jam pada suhu $37^{\circ} \mathrm{C}$. Zona bening yang terbentuk disekeliling cakram diukur dan ditentukan Lebar Daerah Hambat nya (LDH) (Gambar 1). Pengujian ini dilakukan untuk masing-masing konsentrasi ekstrak dengan 4 kali pengulangan. Data yang diperoleh diolah secara statistik menggunakan analisa sidik ragam (Analysis Varian/ANOVA)

Cara penentuan LDH:

$$
\mathrm{LDH}=\frac{D D H-D i s k}{2}
$$

Keterangan:

\footnotetext{
LDH : Luas Daerah Hambatan

DDH : Diameter Daya Hambat $(\mathrm{cm})$

Disk : Ukuran kertas saring $(\mathrm{cm})$
}

Pengujian :

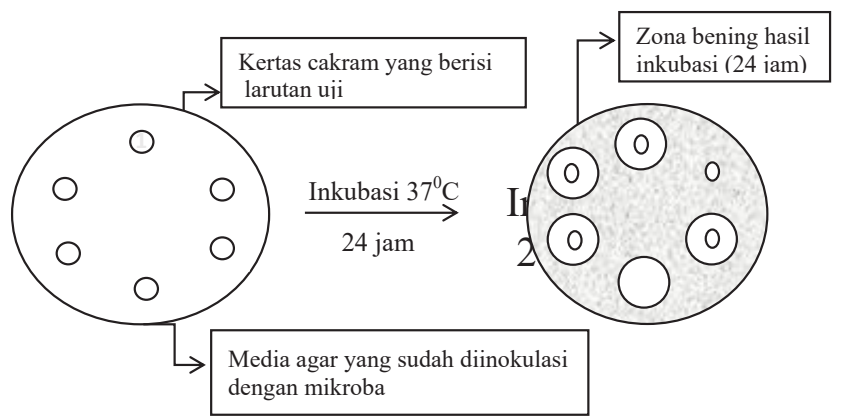

Gambar 1. Letak kertas cakram pada media Nutrien Agar (NA) dan PDA (Potato Dextrose Agar) yang telah di inkubasi dengan Staphylococcus epidermidis, Pseudomonas aeruginosa dan Candida albicans.

Keterangan : 1 : Eritromisin (kontrol positif untuk bakteri) dan ketokonazol (kontrol positif untuk jamur), 2: Akuadestilata (kontrol negatif), 3: Konsentrasi ekstrak 10\%, 4: Konsentrasi ekstrak 12\%, 5:Konsentrasi ekstrak 14\% 6: Konsentrasi ekstrak 16\%

\section{Hasil Dan Pembahasan}

Proses pembuatan serbuk simplisia biji bengkuang terhadap $1,5 \mathrm{~kg}$ biji menghasilkan 425,32 g serbuk simplisia dengan rendemen sebesar 28,3\%. Proses maserasi terhadap $300 \mathrm{~g}$ serbuk menggunakan etanol $70 \%$ yang dilanjutkan dengan proses pengeringan ekstrak menggunakan vaccum drier menghasilkan ekstrak kering sebanyak 57,3 g, dengan perolehan rendemen sebanyak 19,1\% (Gambar 2).
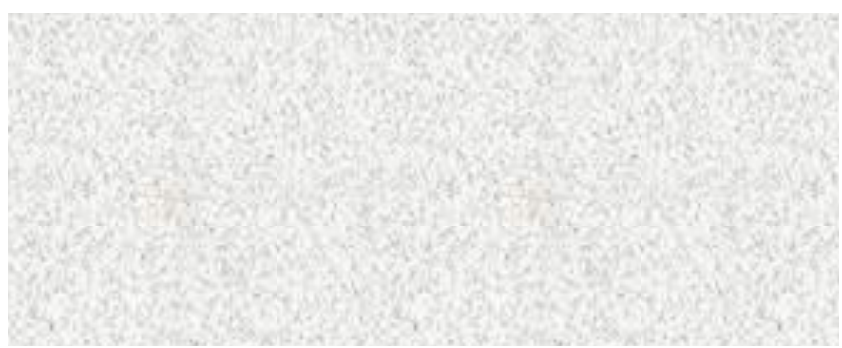

Gambar 2. Serbuk Simplisia Biji Tanaman Bengkuang (a) dan Ekstrak Kering Biji Tanaman Bengkuang

Berdasarkan hasil penentuan kadar air dan kadar abu simplisia, serbuk simplisia biji tanaman bengkuang mengandung kadar air sebesar $7,27 \%$ dan kadar air ekstrak kering biji tanaman bengkuang sebesar $4,02 \%$ dengan rerata kadar abu serbuk simplisia biji bengkuang sebesar 3,40\%. Kadar air dan kadar abu simplisia mapun ekstrak tersebut memenuhi persyaratan kadar air serbuk simplisia yang tertuang dalam materia medika Indonesia edisi 1 (DepKes RI, 1977), yatu persyaratan kadar air simplisia dan ekstrak tidak 
lebih dari 10\% dan kadar abu tidak lebih dari 3,5\% (DepKes RI, 2000).

Hasil uji fitokimia yang dilakukan terhadap serbuk simplisia dan ekstrak kering biji bengkuang menunjukkan kedua sampel tersebut positif mengandung alkaloid, flavonoid, saponin dan tanin (Tabel 1).

Tabel 1. Hasil Penetapan Uji Fitokimia Ekstrak Biji Tanaman Bengkuang

\begin{tabular}{ccc}
\hline $\begin{array}{c}\text { Golongan } \\
\text { Senyawa }\end{array}$ & $\begin{array}{c}\text { Serbuk simplisia } \\
\text { Biji tanaman } \\
\text { Bengkuang }\end{array}$ & $\begin{array}{c}\text { Ekstrak kering } \\
\text { Biji Tanaman } \\
\text { Bengkuang }\end{array}$ \\
\hline Alkaloid & + & + \\
Flavonoid & + & + \\
Saponin & + & + \\
Tanin & + & + \\
\hline
\end{tabular}

Keterangan: tanda (+) positif ada, tanda (-) negatif tidak ada.

Aktivitas antimikroba ekstrak biji bengkuang terhadap Staphylococcus epidermidis, Pseudomonas aeruginosa, serta fungi Candida albicans disajikan pada Gambar 3-4 dan Tabel 2. Hasil uji KBM, menunjukkan adanya pertumbuhan mikroorganisme pada media yang mengandung ekstrak konsentrasi 2,5-7,4 \%, namun pada media tumbuh yang mengandung ekstrak biji bengkuang $10 \%$ tidak teridentifikasi adanya pertumbuhan Staphylococcus epidermidis, Pseudomonas aeruginosa, maupun Candida albicans. Berdasarkan data tersebut maka KBM ekstrak untuk ketiga mikroorganisme tersebut ditetapkan berada pada konsentrasi 10\% (Gambar 3).

Daya inhibisi ekstrak ditentukan berdasarkan hasil uji sensistivitas mikroorganisme terhadap ekstrak pada uji cakram. Lebar Daerah Hambat (LDH) pada uji cakram merupakan refleksi dari diameter zona bening yang terbentuk akibat adanya hambatan pertumbuhan mikroorganisme oleh bioaktif. Nilai LDH ekstrak biji bengkuang terhadap Staphyococcus epidermidis, Pseudomonas aeruginosa, serta Candida albicans disajikan pada Tabel 2.
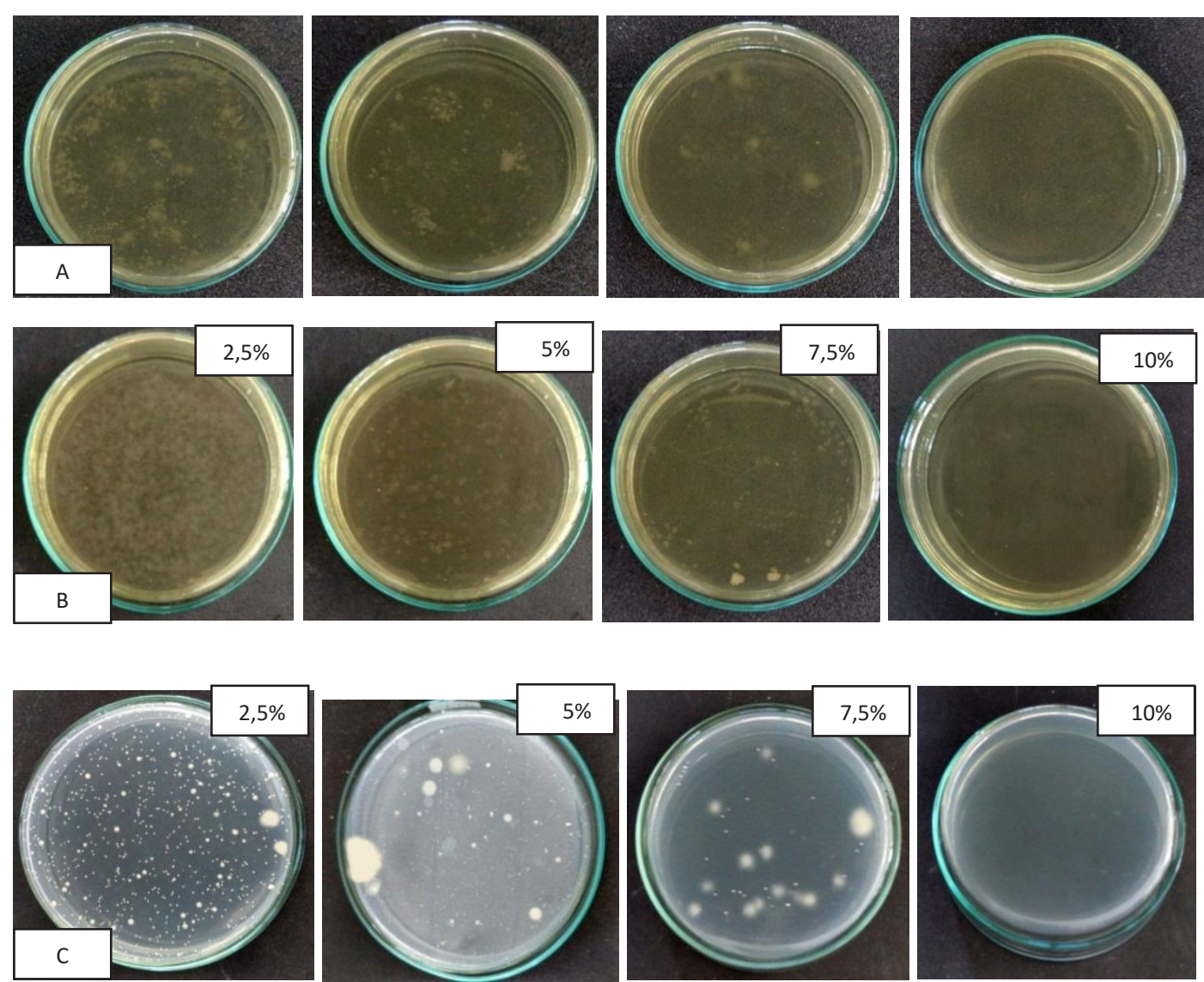

Gambar 3. (a) Hasil Uji Konsentrasi Bunuh Minimum (KBM) Ekstrak Biji Tanaman Bengkuang terhadap Staphylococcus epidermidis; (b) terhadap Pseudomonas aeruginosa dan (c) terhadap Candida albicans 


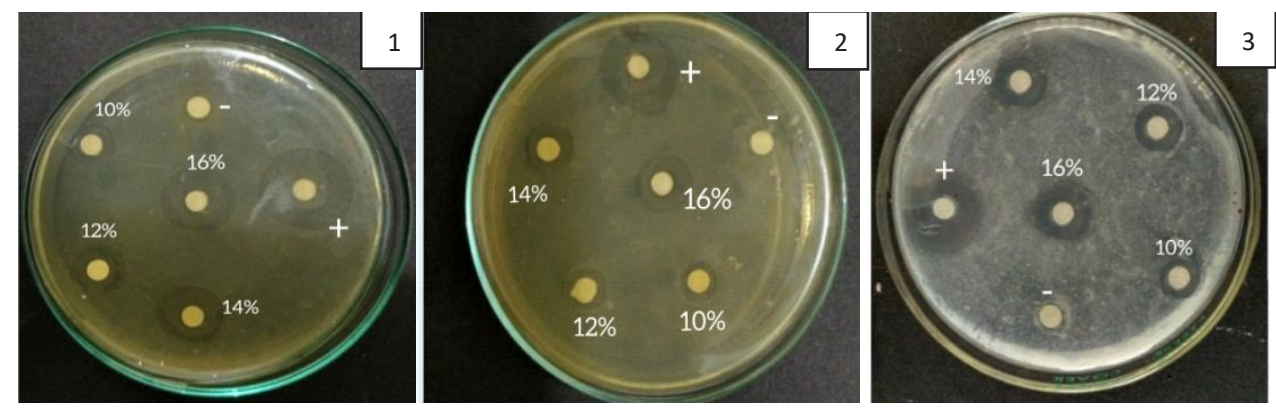

Gambar 4. Hasil Uji LDH Ekstrak Biji Tanaman Bangkuang Terhadap 1) Staphylococcus epidermidis, 2) Pseudomonas aeruginosa, 3) Candida albicans.

Tabel 2. Lebar Daerah Hambat (LDH) Ekstrak Biji Tanaman Bengkuang terhadap Staphylococcus epidermidis, Pseudomonas aeruginosa dan Candida albicans

\begin{tabular}{|c|c|c|c|c|c|c|}
\hline \multirow{2}{*}{ Mikroorganisme } & \multirow{2}{*}{$\begin{array}{l}\text { Kontrol } \\
\text { negatif }\end{array}$} & \multicolumn{4}{|c|}{ Ekstrak } & \multirow{2}{*}{ kontrol (+) } \\
\hline & & 10 & 12 & 14 & 16 & \\
\hline \multicolumn{7}{|l|}{ Staphylococcus } \\
\hline epidermidis $^{b}$ & 0 & $3.54 \pm 0.069$ & $4.04 \pm 0,232$ & $5.43 \pm 0.312$ & $6.55 \pm 0,324$ & $11.40 \pm 0.451$ \\
\hline \multicolumn{7}{|l|}{ Pseudomonas } \\
\hline $\operatorname{aeruginos}^{a}$ & 0 & $2.30 \pm 0.071$ & $2.70 \pm 0.158$ & $4.35 \pm 0.279$ & $5.45 \pm 0.319$ & $11.43 \pm 0.455$ \\
\hline \multicolumn{7}{|l|}{ Candida } \\
\hline albicans $^{b}$ & 0 & $3.46 \pm 0.138$ & $4.01 \pm 0.085$ & $5.35 \pm 0.279$ & $6.46 \pm 0.342$ & $11.39 \pm 0.464$ \\
\hline
\end{tabular}

Keterangan. Huruf superskrip yang berbeda pada kolom yang sama menunjukkan adanya perbedaan efek ekstrak yang signifikan terhadap mikroorganisme uji (ANOVA $\mathrm{P}<0.05$ dilanjutkan dengan Duncan $\mathrm{P}<0.05$ ). namun tidak berlaku untuk

Data yang disajikan pada Tabel 2 menunjukkan bahwa kontrol negatif memiliki LDH 0 yang berarti tidak ada aktivitas antimikroba. Aktivitas antimikroba ditunjukkan oleh ekstrak biji tanaman bengkuang pada konsentrasi $10 \%$ dengan nilai rata - rata LDH ekstrak yaitu $3.54 \pm 0.069$ $\mathrm{mm}$ untuk bakteri Staphylococcus epidermidis, $2.30 \pm 0.071 \mathrm{~mm}$ untuk bakteri Pseudomonas aeruginosa, dan $3.46 \pm 0.138 \mathrm{~mm}$ untuk jamur Candida albicans. Nilai LDH ekstrak terhadap ketiga mikroorganisme tersebut semakin tinggi sejalan dengan bertambahnya konsentrasi ekstrak dari $12 \%, 14 \%$ dan $16 \%$ secara berturut - turut yaitu $4.04 \pm 0,232 \mathrm{~mm}, 5.43 \pm 0.312 \mathrm{~mm}, 6.55 \pm$ $0,324 \mathrm{~mm}$ untuk Staphylococcus epidermidis, 2.70 $\pm 0.158 \mathrm{~mm}, 4.35 \pm 0.279 \mathrm{~mm}, 5.45 \pm 0.319 \mathrm{~mm}$ untuk Pseudomonas aeruginosa, dan $4.01 \pm 0.085$ $\mathrm{mm}, 5.35 \pm 0.279 \mathrm{~mm}, 6.46 \pm 0.342 \mathrm{~mm}$ untuk Candida albicans. Dengan demikian, konsentrasi terbaik yang dapat membunuh mikroorganisme dari ekstrak biji bengkuang pada percobaan ini adalah $16 \%$. Namun, aktivitas antimikroba dari ekstrak biji bengkuang pada konsentrasi tersebut masih lebih kecil dibandingkan dengan kontrol positif.

Hasil analisa statistik dengan ANOVA, menunjukkan adanya perbedaan aktivitas antimikroba ekstrak yang signifikan terhadap ketiga mikroorganisme tersebut (ANOVA, $\mathrm{P}<0.05$ ). Aktivitas antimikroba ekstrak terhadap Pseudomonas aeruginosa ialah paling rendah diikuti dengan aktivitas antimikroba terhadap Candida albicans dan aktivitas antimikroba ekstrak terhadap Staphylococcus epidermidis (ANOVA dilanjutkan Duncan $\mathrm{P}<0.05$ ).

Pseudomonas aeruginosa adalah bakteri gram negatif yang kurang sensitif dibandingkan dengan Staphyococcus epidermidis dan Candida albicans terhadap ekstrak biji bengkuang. Struktur dinding bakteri gram negatif mempunyai membrane luar (Outer membrane) yang melindungi bakteri dari beragam antibiotik, bahan kimia dan detergen. Struktur dinding bakteri gram positif lebih sederhana dibandingkan dengan struktur bakteri gram negatf. Hal ini menyebabkan senyawa antimikroorganisme dari ekstrak biji bengkuang lebih mudah menembus dinding dan masuk ke dalam sel bakteri gram positif daripada menembus 
dinding sel bakteri gram negatif (Peng et al., 2017).

Hasil penelitian ini juga menunjukkan bahwa selain aktivitas antimikrobanya rendah, potensi antimikroba ekstrak terhadap Pseudomonas aeruginosa juga lebih rendah dibandingkan dengan potensi antimikroba ekstrak terhadap Staphylococcus epidermidis dan Candida albicans. Potensi antimikroba ekstrak pada konsentrasi $16 \%$ terhadap kontrolnya ialah 57,5 untuk Staphyococcus epidermidis, 47,7 untuk Pseudomonas aeruginosa, dan 56,7 \% untuk Candida albicans. Potensi antimikroba dihitung berdasarkan $\mathrm{LDH}$ tertinggi dibagi dengan LDH kontrol positif dikali $100 \%$.

Aktivitas antimikroba ekstrak biji bengkuang terhadap Pseudomonas aeruginosa dibandingkan dengan tanaman Yasmin dan Mayana juga masih rendah. LDH ekstrak Yasmin offisinale baik berupa ekstrak air dingin dan ekstrak air hangat terhadap Pseudomonas aeruginosa masing masing ialah 16 dan $9 \mathrm{~mm}$ (Khan et al., 2013). LDH ekstrak etanol daun Mayana konsentrasi $10 \%$ ialah $8 \mathrm{~mm}$ (Mpila et al., 2012).

Davis and Stout (1971) memaparkan potensi antimikroba berdasarkan lebar daerah hambat. Diameter zona hambat, yaitu $5 \mathrm{~mm}$ atau $<5 \mathrm{~mm}$ dikatagorikan lemah, 5-10 mm dikatagorikan sedang zona 10-20 dikatagorikan kuat, lebih atau sama dengan $20 \mathrm{~mm}$ dikatagorikan sangat kuat. Pada konsentrasi tertinggi yaitu $16 \%$, ekstrak biji bengkuang mempunyai $\mathrm{LDH}<5 \mathrm{~mm}$ namun kurang dari $10 \mathrm{~mm}$. Berdasarkan klasifikasi tersebut maka ekstrak biji bengkuang mempunyai aktivitas antimikroorganisme yang termasuk ke dalam katagori sedang.

Flavanoid, saponin dan tanin diduga berperan penting terhadap aktivitas antimikroba biji bengkuang. Robinson (1995) mengemukakan bahwa flavonoid, saponin dan tannin mempunyai aktivitas antibakteri melalui mekanisme kerja yang berbeda. Flavanoid bekerja sebagai antibakteri melalui proses denaturasi dan koagulasi protein sel bakteri yang mengakibatkan sel bakteri mati, sedangkan saponin bekerja sebagai antibakteri melalui peningkatan permeabilitas membran sehingga terjadi hemolisis sel. Selain itu, saponin bekerja sebagai antimikroorganisme dengan cara membentuk ikatan yang stabil dengan protein yang menyebabkan terjadinya koagulasi protoplasma (Robinson, 1995).

Sejalan dengan penelitian ini, Wiredu (2014) melakukan penelitian terhadap kandungan polifenol biji, daun dan akar bengkuang. Hasilnya menunjukkan keberadaan polifenol dengan kandungan polifenol tertinggi terdapat pada akar diikuti oleh biji dan daun, selain itu juga diketahui adanya perbedaan komposisi kandungan fitokimia pada akar, biji dan daun. Namun Wiredu (2014) tidak melaporkan adanya flavonoid dalam ekstrak etanol $70 \%$ biji bengkuang. Perbedaan potensi eksktrak biji bengkuang untuk Pseudomonas kemungkinan terjadi karena adanya perbedaan tempat tumbuh dari tanaman bengkuang yang diambil bijinya sebagai objek dalam penelitian ini.

Ekstrak biji bengkuang pada penelitian ini masih termasuk ke dalam ekstrak kasar. Beragam senyawa kimia masih terdapat di dalam ekstrak sehingga aktivitas antimikroba yang muncul merupakan hasil dari resultante kinerja senyawa yang ada di dalamnya baik sebagai agonis maupun antagonis, Oleh karena itu, penelitian lebih lanjut perlu dilakukan untuk mengetahui senyawa dalam ekstrak bengkuan yang berpotensi sebagai antimikroorganisme

\section{Kesimpulan}

Ekstrak biji tanaman bengkuang memiliki aktivitas terhadap bakteri Staphylooccus epidermidis dan Pseudomonas aeruginosa, serta fungi Candida lbican dengan nilai KBM $10 \%$. Semakin tinggi konsentrasi ekstrak biji tanaman bengkuang, maka semakin besar aktivitas dalam membunuh mikroba. Flavonoid, saponin dan tannin merupakan bioaktif dari ekstrak etanol biji bengkuang yang diduga mempunyai efek antimikroorganisme terhadap ketiga mikroorganisme tersebut.

\section{Daftar Pustaka}

Bella, B.Y and Lynn, E.V. (1953). Examination of the Seed of Pachyrrhizus erosus. Journal of the American Pharmaceutical Association (Scientific ed.). 42 ( 2) : 117-118.

Davis, W. W., dan Stout, T. R.( 1971). Disc Plate Method of Microbiological. Antibiotic 
Assay. Applied Microbiology. 22 (4): 659665.

Dep. Kes RI. (1977). Materia Medika Indonesia, Edisi III. Direktorat Pengawasan Obat dan Makanan. Jakarta.

Dep. Kes RI. (1978). Materia Medika Indonesia. Jilid II. Jakarta. Direktorat Pengawasan Obat dan Makanan. Hal : 49-150.

Dep. Kes RI. (1980). Materia Medika Indonesia. Jilid IV. Cetakan Pertama. Jakarta : Direktorat Jendral Pengawasan Obat dan Makanan.

Dep. Kes RI. (1985). Cara Pembuatan Simplisia. Direktorat Pengawasan Obat dan Makanan. Jakarta. Hal : 1-22.

Dep. Kes RI. (2000). Parameter Standar Umum Ekstrak Tumbuhan Obat. Direktorat Jendral Pengawasan Obat dan Makanan.:

Fransworth, N.R. (1966). Biological and Phytochemical Screening Of Plants. Journal od Pharmaceutical Sciences. 55 ( 3) : 262-264.

Jadhav, V.J., and Pal, L. M. (2013). Human and domestic animal infections caused by Candida albicans. J. Mycopathol. Res. 51(2): $243-249$.

Juriah, J. (2003). Fraksinasi Ekstrak Biji Bengkuang (Pachyrrhizus erozus) yang Berpotensi Sebagai Antibakteri. Skripsi. IPB. Bogor :

Khan, U.A., Rahman, H., Niaz, Z., Qassim, M., Khan, J., Tayyaba and Rehman, B. 2013. Antibacterial activity of Some Medicinal Plants Against Selected Human Pathogenic Bacteria, European Journal of Microbiology and Immunology 3 (4): 272-274.

Kumalasari, I.D., Nishi, K., Harmayani, E., Raharjo, S., Sugahara, T. (2014). Immunomodulatory Activity of Bengkoang ( $\mathrm{Pa}-$ chyrhizus Erosus) Fiber Extract In Vitro And In Vivo. Cytotechnology. 66(1):75-85.

Koneman, E.W., Allen, S.D,. Janda, W.M., Schreckenberger, P.C., and Winn, W.C. (1997). Color atlas and Textbook of Diagnostic Microbiology. Fifth Edition. Lippincott Williams \& Wilkins, a Wolters Kluwer Company. Page : 171-199.
Levinson, W.M.D., and Jawetz, E. (2003). Medical Microbiology And Immunology (Examination and Board Review). Seventh edition. McGraw Hill Companies. Nort America : 286 - 288.

McKane, L. and Kandel, J. (1996). Microbiology: Essentials and Applicationts. McGraw-Hill. New York.

Mpila, D. A., Fatimawali., \& Wiyono, W. I. (2012). Uji Aktivitas Antibakteri Ekstrak Etanol Daun Mayana (Coleus atropurpureus [L] Benth) Terhadap Staphylococcus aureus, Eschericia coli, dan Pseudomonas aeruginosa secara In Vitro (online) (http://ejournal.unstrat.ac.id/index.php/ pharmacon/article/view/440/351, diakses tanggal 10 Mei 2013).

Necha, L.L.B., Baños, S.B., Luna, L.B., Suárez, F.J.L.G. (2004). Antifungal Activity of Seed Powders, Extracts, and Secondary Metabolites of Pachyrhizus erosus (L.) Urban (Fabaceae) Against Three Postharvest Fungi. Revista Mexicana de FITOPATOLOGIA, 22(3):356-361.

Nines, K.R (1999). Inulin and Oligofruktosa what are they. Jurnal of Nutrition. 129 :1402S$1406 \mathrm{~S}$

Parra, E.A.E., Verjana, J.C.G., Sa 'nchezab, I. G.L., Mart1 'nez b,E.R.V., Castaneda, E.V., , Cerbon. M.A., Solano, D.A., andChilpaa.R.R. (2014). Rotenone Isolated From Pachyrhizus Erosus Displays Cytotoxicity And Genotoxicity In K562 Cells .Natural Product Research. 28 ( 20): 1780-1785.

Peng, B., Wang, C., Li, H., Su, Y.B., Ye, J.Y., Yang, M.J.M., and Peng. X.X. (2017). Outer Membrane Proteins form Specific Patterns in Antibiotic-Resistant Edwardsiella tarda. Front Microbiol.8: 69.

Radji, M.(2011).Buku Ajar Mikrobiologi Panduan Mahasiswa Farmasi dan Kedokteran. Jakarta : Buku Kedokteran EGC. Hal 201207.

Robinson, T. (I995). Kandungan Organik Tumbuhan Tinggi. Bandung : ITB. Hal 
$132,157,191$.

Roberfroid, M.B. (2015) Prebiotic and Probiotic are They Functional Food. J. Clint. Nytr.18:117-143.

Rubatzky, V. E. dan Yamagutchy, M. (1998). Sayuran Dunia. Jilid ke-2. Bandung: ITB.

Santos, A.C., Cavalcanti, M.S., Coelho, L.C.(1996). Chemical Composition And Nutritional Potential Of Yam Bean Seeds (Pachyrhizus Erosus L. Urban). Plant Foods Hum Nutr. 49(1):35-41.

Wiredu, C.B. 2014. Evaluation of Starch properties, Phytochemical Composition and Antimicrobial Activities of Yam Bean (Pachyrhizus erosus (L Urban.). Thesis Kwame Nkrumah University of Science and Technology.

Wesley, A.V., dan Margaret, F.W. (1989). Mikrobiologi Dasar. Edisi 5 jilid II. LIPI. Jakarta:Erlangga. Hal 155,156,157,195,196.

Woodford, N., Turton, J..F., and Livermore, D.M. (2011). Multiresistant Gram negative
Bacteria: the Role of High-Risk Clones In The Dissemination OfAntibiotic Resistance. FEMS Microbiol Rev.35(5): 736-55. https:// doi.org/10.1111/j.1574-6976.2011.00268.x PMid:21303394.

Zavascki, A.P., Zavascki, A.P., Carvalhaes, C.G., Picão ,R.C., Gales, A.C. (2010). MultidrugResistant Pseudomonas aeruginosa and Acinetobacter baumannii: Resistance Mechanisms and Implications for Therapy. Expert Rev Anti Infect Ther. 8(1):7193. https://doi.org/10.1586/eri.09.108 PMid:20014903.

Zowalaty, M.E., Al Thani, A.A., Webster,T.J., El Zowalaty,A.E., Schweizer,H.P., Nasrallah, G.K., Marei, H.E., Ashour, H.M. (2015) Pseudomonas aeruginosa: arsenal of resistance mechanisms, decades of changing resistance profiles, and future antimicrobial therapies. Future Microbiol.10 (10): 1683706. https://doi.org/10.2217/fmb. 15.48 PMid:26439366 